\title{
VOLTAIRINE DE CLEYRE: MORE OF AN ANARCHIST THAN A FEMINIST?
}

\author{
STEVE J.SHONE*
}

IN RECENT YEARS, there has been significant interest in the writings of Voltairine de Cleyre (1866-1912), with a number of authors attempting to reassess her work, in some cases drawing increased attention to the perspective that her ideas constitute a form of feminism. Remembered also as a poet, anarchist, and atheist, de Cleyre was born in Leslie, Michigan, a small town south of Lansing. Her parents, who were impoverished tailors, left Leslie when Voltairine was about one year old, following the accidental drowning death of another daughter, Marion, at the age of five. The family moved to St. Johns, Michigan, a town on the north side of Lansing (Avrich 1978, 19-20; Havel [1914] 2005, 7). Despite the objections of Voltairine's mother, her father, an atheist and admirer of Voltaire, created her distinctive given name to commemorate his own beliefs (Avrich 1978, 19; Havel [1914] 2005, 7; Palczewski 1955, 54; Sartwell 2005, 4).

Schooled at the Convent of Our Lady of Lake Huron, in Sarnia, Ontario, de Cleyre rebelled against the physical and intellectual rigidity of her training and rejected religion, although some commentators feel that she retained a somewhat clerical demeanor, which DeLamotte $(2004,35)$ refers to as "an emotional kinship to the religious sensibility." Her ally in anarchism,

*Steve J. Shone, Ph.D. may be reached at loser@justice.com. His book, Lysander Spooner: American Anarchist will be published by Lexington Books in May, 2010. A version of this paper was presented at the Annual Meeting of the Northeastern Political Science Association, in Philadelphia, Pennsylvania, November 15-17, 2007. The author is grateful to Francine D'Amico, Kathleen Iannello, Lee MacLean, and Catherine Palczewski for helpful comments on earlier drafts.

CiTE THIS ARTICLE AS: Steve J. Shone, "Voltairine de Cleyre: More of an Anarchist than a Feminist?”, Libertarian Papers 2, 8 (2010). ONLINE AT: libertarianpapers.org. THIS ARTICLE IS subject to a Creative Commons Attribution 3.0 License (creativecommons.org/licenses). Published by the Ludwig von Mises Institute. 
the better-known Emma Goldman ([1932] 2005, 39), believed that these formative years undermined de Cleyre's confidence, a condition that would last for the rest of her life. Called Voltai by people who were close to her, de Cleyre spent a sizable part of her existence in Philadelphia, where she taught English to Jewish immigrants, as a consequence acquiring some mastery of Yiddish herself (Streeby 2007, 420). Goldman (35) speculates that the many hours a day occupied teaching pupils, which she terms "drudgery," contributed to her friend's constant condition of exhaustion. A prolific speech-giver, de Cleyre was sometimes able to travel, and she visited Britain, where she met the Russian anarchist prince, Peter Kropotkin, as well as Norway, where she was trailed by police. She wrote articles for both Liberty, the journal of the American Anarchist, Benjamin R. Tucker, and for mainstream anarchist Goldman's Mother Earth. In 1902, she was shot by one of her students, Herman Helcher. Unbalanced and malnourished, Helcher portrayed himself to police as a jilted lover of Voltairine, whom he felt was now persecuting him, and this appears to be the motive for the attack (Avrich 1978, 173; Sartwell 2005, 7).

Characteristically, and in the tradition of some other revolutionaries, de Cleyre declined to prosecute her assailant. Her health never fully recovered from this incident, and sometimes her impaired condition caused her to contemplate suicide. However, she lived for another decade, eventually being buried in Waldheim Cemetery in the suburbs of Chicago, ${ }^{1}$ where Goldman would later also be interred (Avrich 1978, 9, 20, 29; Hogeland and Klages 2004, 1342; Sartwell 2005, 3).

De Cleyre's literary writings were proficient, although they never concealed her political motives. Pateman (2004, iii) points out that one of the purposes of de Cleyre's stanzas was to show her "support of those who have used violence, and her desire to memorialize and celebrate their courage." Franklin Rosemont, the surrealist bard, called her "a remarkable poetindeed, probably the greatest poet-activist in U.S. anarchist history" (5), observing also that "readers of her essays and speeches can tell at once that they are reading the work of a poet" (10).

A number of scholars who make reference to de Cleyre say she was an anarchist, but do not call her a feminist. For instance, Fidler $(1985,107)$ refers to her as "the American Anarchist Voltairine de Cleyre." Bright (2006, 20) calls her an "individualist anarchist." Oberdeck $(2007,436)$ refers to her as a contributor to a "circle of anarchist papers." Brouwer (2004, 209) describes her as a writer of "anarchist rhetoric." Kensinger $(2003,3)$ speaks

${ }^{1}$ Now part of Forest Home Cemetery. 
of "the anarchist Voltairine de Cleyre," and Weir (1997, 139) calls her "the American anarchist Voltairine de Cleyre." In one place, McElroy (2000, 110) refers to " $\mathrm{t}]$ he individualist anarchist Voltairine de Cleyre," though in another article, she tags her as a feminist $(2001,16)$, and, in a more recent work, she calls her an "Individualist Anarchist and feminist" (2003, 38).

Similarly, Meltzer $(1996,378)$ includes her "among the anarchists of the past such as the Chicago Martyrs, Lucy Parsons, Voltairine de Cleyre and Harry Kelly." Martin $(1970,261)$ portrays her as "part of the native anarchist movement." In a letter written by Eugene Debs $(1990,265)$ and dated May 1908, the leading socialist wrote, "Of course you know that I am not an anarchist and do not agree to the anarchist philosophy, but I can none the less admire such a comrade as Voltairine de Cleyre." Elsewhere, she is referred to as one of "such pivotal anarchists as Emma Goldman, Alexander Berkman, Voltairine de Cleyre, among countless others" (Sakolsky 2005, 134). Ottanelli (1997) lists de Cleyre as one of several "prominent anarchists." while Brammer $(2000,12)$ also deems de Cleyre "a prominent anarchist," and Halker $(1991,66)$ terms her a "fellow anarchist" to her friend, Dyer D. Lum.

Reichert (1976, 339) calls de Cleyre "[o]ne of the most beautiful souls ever to adopt the libertarian teachings of anarchism." Pateman $(2004$, i) says that "de Cleyre consciously set out to create a specifically anarchist history." Henderson $(2003,13)$ speaks of "one individual (Voltairine de Cleyre) who is today regarded as a example of the ideal of anarchism in Philadelphia." Later (18), she notes that "Voltairine de Cleyre remains a strong influence for the current anarchist movement in Philadelphia." McKinley (1987, 389) names her as "the American-born anarchist Voltairine de Cleyre," although, in an earlier paper $(1982,513)$, he speaks also of "her ideologies of secularism, feminism, and anarchism." Herrada and Hyry (1999) call de Cleyre "a Michigan-born anarchist and friend of Emma Goldman." Writing about Lum, Brooks $(1993,58)$ notes that historians have often cast him as a lesser figure, being merely "a comrade of other more famous anarchists such as Albert Parsons, Voltairine de Cleyre, or Benjamin Tucker." In another work, Brooks $(1994,11)$ observes that de Cleyre was one of a number of "writers" who "have insisted that anarchism is peculiarly suited to America." In his introduction to Emma Goldman's Anarchism and Other Essays, the Czech-born anarchist, Hippolyte Havel $(1910,13)$, describes Goldman and de Cleyre as " $[\mathrm{t}]$ he two most prominent representatives of the Anarchist idea in America." He does not make note of the fact that they were both women.

Other commentators make some mention of de Cleyre's gender without specifically calling her a feminist. Marsh (1981, 123), for instance, proclaims her "the second most important woman in the American anarchist movement," although elsewhere $(1978,541)$ she concludes that "de Cleyre 
systematized the anarchist-feminist perspective." For Kaye $(2005,178)$, de Cleyre and Goldman became "the anarchist movement's foremost women activists." Huberman $(2006,72)$ feels that de Cleyre was not only the most talented female American anarchist, but also a "women's rights and labor activist" and a "renowned atheist lecturer." Streeby $(2007,411)$ refers to "prominent anarchist women, including Lucy Parsons and Voltairine de Cleyre," as well as to the "anarchist poet, essayist, and orator Voltairine de Cleyre" (420). Wexler $(1981,123)$ describes de Cleyre as an anarchist who once gave a lecture on the "eighteenth-century feminist," Mary Wollstonecraft. For her contemporary, Emma Goldman, de Cleyre was simply "this most gifted and brilliant anarchist woman America ever produced" (Goldman [1932] 2005, 29; Huberman 2006, 72).

Some observers see her more explicitly as both an anarchist and a feminist. Sartwell $(2005,3)$ portrays her as both, and also lauds the reputation of de Cleyre and Goldman as "the two great women of American anarchism." Mullaney $(1990,300,316)$ includes de Cleyre in her lists of both "radical women" and "anarchist women." Molyneux $(1986,123)$ describes de Cleyre as someone from North America participating in the development of a form of anarchism that included "a distinctive feminist current." Best and Nocella (2007) describe de Cleyre as an "American anarchist and feminist writer." Tone (2006, 232) writes of "the noted anarchist and feminist Voltairine de Cleyre." Palczewski $(1993,152)$ calls her "a largely untapped feminist resource," and describes her intellectual progression as follows: "Originally a freethinker and socialist, she became an anarchist and feminist" (143). Later, she cautions that "De Cleyre rarely combined her views of women and anarchism in the same discourse" (146). In another article, she describes de Cleyre as follows:

De Cleyre is an important rhetorical and feminist figure because her anarchist feminism is an early precursor to many of the radical critiques of women's sexual status that came out of the "second wave" of feminism. (Palczewski 1995, 55)

Rosemont (1990, 5) describes de Cleyre as "one of the foremost American exemplars of international anarchism," but says also that "a strong feminist dimension distinguished De Cleyre's anarchism from most other anarchisms" (7). DeLamotte $(2004,4)$ says starkly that "Voltairine de Cleyre was an American anarchist feminist." Presley (2005b, 17) describes de Cleyre as being "even less known among feminists today than among anarchists." Accepting her inclusion in a study of "anarchist women," Marso (2003, 313) refers to her also as "Goldman's contemporary, feminist Voltairine de Cleyre" (313). 
Sometimes, even though scholars attribute feminism to Voltairine de Cleyre, the feminism may nonetheless be explained as an aspect of her anarchism. Discussing director Lina Wertmüller's movie, "Swept Away," Russo Grace $(2007,67)$ coins the term "anarcha-feminism," arguing that anarcha-feminists such as Wertmüller believe that "the gender struggle is an integral part of the class struggle and both are a fundamental part of the "anarchist" struggle against the state." He continues by noting that anarchafeminism was "inspired by early twentieth century thinkers and authors like Emma Goldman and Voltairine de Cleyre" (67). Similarly, although in Anarchist Portraits, Paul Avrich $(1990,87)$ describes her as "Voltairine de Cleyre, the American anarchist poet," in his book devoted to de Cleyre, Avrich $(1978,158)$ writes: "Voltairine de Cleyre's whole life was a revolt against this system of male domination which, like every form of tyranny and exploitation, ran contrary to her anarchistic spirit." Margaret Marsh concludes that, although Avrich's book "includes a brief discussion of her feminist philosophy, for the most part the focus is on the anarchist movement" (Marsh 1981, 124). Marsh focuses a chapter of her own book on de Cleyre as a woman struggling to succeed: “The organized women's rights movement was too conventional for her, although she considered herself a feminist and expressed admiration for the suffragists" (Marsh 1981, 128). Horwitz, Kowal, and Palczewski $(2008,631)$ present de Cleyre, Goldman, and Lucy Parsons as "representative of feminist anarchism in all its complexity."

Other authors see her primarily through the prism of her feminism, rather than as an anarchist. For example, Hecht $(2004,412)$ describes de Cleyre as "a renowned atheist lecturer," and as an advocate of "atheism, as well as women's rights and labor rights." Brigati (2004, vii) calls her "both a political activist and women's rights advocate."

Several writers reference a connection between de Cleyre and Mary Wollstonecraft, the eighteenth-century British author of $A$ Vindication of the Rights of Woman. For example, DeLamotte writes:

One of de Cleyre's great predecessors in the disruption of false images of women was Mary Wollstonecraft (1759-1797), whose pervasive influence on her feminism is evident ... De Cleyre was demonstrably influenced by Wollstonecraft's view of marriage as a form of prostitution. (DeLamotte 2004, 212)

Correspondingly, Marsh $(1978,542)$ observes:

De Cleyre deplored the legalistic and political emphases of the woman's [sic] rights movement of her own day ... Intellectually, she was far more compatible with such isolated rebels as Mary Wollstonecraft, in honor of whom she wrote poetry and delivered lectures. 
De Cleyre's biographer, Paul Avrich $(1978,14)$ writes about her "striking resemblance to Mary Wollstonecraft, the inaugurator of the modern women's rights movement, about whom she often wrote and lectured." Indeed, de Cleyre $(2005,217)$ did admire Wollstonecraft, and, in 1893, she penned a poem entitled "Mary Wollstonecraft," a eulogy that ends with the line, "She liveth still” (De Cleyre [1914] 2005, 49; 1990, 31; 2004, 208).

\section{Voltairine De Cleyre as an Anarchist}

That Voltairine de Cleyre is rightfully classified as an anarchist, and, moreover, one who has been sadly neglected by scholars, is not a difficult proposition to accept. One of the key confirming factors is surely the events that have come to be called the Haymarket Tragedy and de Cleyre's reaction to them, including her confrontation of the reality of what she considered judicial murder in the United States.

Paul Avrich (1980, i) calls the events at Haymarket Square in Chicago on May 4, 1886 "one of the most famous incidents in the history of the anarchist movement." Police tried to close a meeting of anarchists who were protesting the violence of the previous night, when officers had fired into a crowd of strikers from the McCormick Reaper Works, killing several people. A bomb was thrown by an unknown assailant, and the radical leaders were blamed for the bombing, and prosecuted for conspiracy to commit murder. These events would eventually be described by de Cleyre $(1980,35)$ as follows: "A peaceable meeting of protest against a murderous attack of the police on strikers."

Seven anarchists were arrested. An eighth, Albert Parsons, who had left the meeting before the bomb was thrown, voluntarily turned himself in, believing there was no chance that he could be found guilty, but all eight were convicted and seven sentenced to hang. Two had their death penalties commuted to life imprisonment, and one received a sentence of fifteen years. Four were executed, but the fifth, Louis Lingg, cheated the hangman by committing suicide in advance of the appointed hour. In 1893, the three men who were still alive and in jail were pardoned because of the obvious unfairness of the trial by Governor John P. Altgeld (Avrich 1980; De Cleyre 1980, 8; DeLamotte 2004, 4-5); for de Cleyre, this was an act of benevolence that she notes in the introduction to her poem, "John P. Altgeld," would end the Illinois politician's career (De Cleyre [1914] 2005, 56; 1990, 31). Haymarket, it is clear, is important because it was a catalyst that confirmed de Cleyre as an anarchist, and it is the key to understanding the sort of anarchist that she was. As DeLamotte $(2004,5)$ notes, the event forced de Cleyre to ask herself "whether "justice under law" is ever possible." The knowledge 
that the police and the government could kill innocent men brought out the harsh reality of life in the United States:

It is all false that the hanging was done because of their preaching violence; it is not violence the ruling classes object to; for they themselves rule by violence . . . It is the social change they fear, the equalization of men. (De Cleyre 1980, 21)

Temporarily living a secluded life in St. Johns, de Cleyre had initially been outraged by reports of the Haymarket bomb, and had called for the perpetrators to be executed (Avrich 1978, 49; Reichert 1976, 340). "I believed the newspapers," she would say later. "I thought those men had thrown that bomb, unprovoked, into a mass of men and women" (De Cleyre 1980, 23). Soon, her growing conviction that the judicial aftermath was, rather, the trial of people who had merely spoken out caused her to change her evaluation. Many years later, she (39) would say that "[t] he world outside our country thinks very correctly that our comrades were tried for being Anarchists and hanged for being Anarchists." In fact, she pointed out that a significant number of people's political beliefs changed as a result of the framing of the Chicago anarchists_ " "for every drop of blood you spilled on that November day you made an Anarchist" (3). In another speech, the rhetoric is identical:

$[\mathrm{M}]$ any a one will say with me tonight, in answer to the question, "What made you an Anarchist?" "The hanging in Chicago." (De Cleyre 1980, 21)

In a speech delivered in Boston nine years after the Haymarket Tragedy, de Cleyre asked:

What is the most priceless lesson we can learn from the martyrdom of Parsons, Fischer, Engel, Lingg, and Spies? (De Cleyre 1980, 1)

For de Cleyre herself, the lesson was surely an anarchist one, that the state, the police, and the legal system were quite capable of lynching their political opponents. Later in her life, she would refer to "the five men done to death by the State of Illinois 23 years ago" (44).

Streeby (2007, 428, fn 1) notes that "Haymarket is a pivotal event in many narratives of US labor history." Moreover, for anarchists like de Cleyre, Haymarket represented a breaking point that, at least in the rhetoric they used, assumed a spiritual significance. For example, McKinley $(1987,389)$ observes that, in a speech, the anarchist William Bailie compared the Haymarket executions to the crucifixion of Jesus. Explaining the pious language used by de Cleyre, notwithstanding her own lack of religious faith, when she wrote about the incident and trial, McKinley concludes that "she understood the power of religious imagery long after she had rejected all dogma" (389). Nor was interpretation of the outrage limited to political 
oratory and tracts. It has been argued that the Haymarket killings influenced Herman Melville's novel, Billy Budd, changing its final form, as well as a number of other literary works (see, for example, Carter 1950; Wallace 1975).

Other commentators have proffered quite different interpretations of what took place to de Cleyre's. Most of the journalists of the time called for blood. Salvatore $(1985,772)$ notes that "[ $t$ ]he city's newspapers, its leading citizens, and its business community almost unanimously charged that the deed was the responsibility of Chicago's anarchist community."

Among scholarly writers who are more skeptical about the goals of the Chicago radical community, Landsman (1986, 832-33) writes that "[t]he Haymarket defendants were men of high principles, but they were political zealots, not saints. Guaneri $(1985,79)$ complains that "in preaching "propaganda by deed," many of the anarchists—including at least three of the Haymarket defendants - applauded assassination, routinely carried dynamite, and urged violent retaliation against police." Similarly, DeMille notes:

The defense was not a denial that the accused men had for years advocated the use of physical force. It was not a denial that they had, on that very May 4th, printed the exhortation "To arms!" and "Revenge!" and "Workingmen arm yourselves and appear in full force!" in their dailies and in circulars spread among the desperate unemployed. It was not a denial that one of them had been making bombs similar in workmanship to the one that produced such devastating results. It was a denial that there was proof that any one of the eight defendants had thrown this particular bomb. (DeMille 1946, 546)

Sartwell $(2005,5)$ describes Haymarket simply as "an explosion to which the anarchist leaders were never convincingly connected."

Despite the continuing debate, de Cleyre's revised take on what had happened at Haymarket is today echoed by the majority of analysts, just as it was by the state governor, even if others do not share her conclusions about the possibilities for justice in the United States. For example, DeLamotte writes:

John Altgeld, governor of Illinois concluded in 1893 after an extensive review of the trial that every aspect of it-from the selection of obviously biased jurors, to police influence of testimony with threats of torture and bribes of money and jobs, to the sheer "fabrication" of evidence, to the judge's unprecedented final instructions to the jury that the state need not prove that the defendants had influenced the perpetrator or even find out who the 
perpetrator was-represented a serious miscarriage of justice. (DeLamotte 2004, 5)

De Grazia (2006, 310) says that Governor Altgeld came to "the same conclusion reached by many dispassionate observers before him, and most such observers after him-there was no particle of evidence that any of the convicted men knew or had anything to do with whoever threw the bomb that killed the policemen at Haymarket." Laslett $(1987,192)$ refers to the trial as "judicial murder."

The two prominent contemporary book-length studies of Haymarket by Avrich (1984) and Green (2006) are compatible with de Cleyre's revised viewpoint, although both authors have their critics. For instance, Oliver (2007, 147) says of Green's book that it would have benefited from the inclusion of "a detailed presentation from the police perspective." Similarly, Guaneri $(1985,78)$ criticizes Avrich's portrayal with the comment that " $[t]$ he fair-minded reader might like to know more about Judge Joseph Gary's background prior to the case and to hear his published defense of the trial." Additionally, Dubofsky $(2007,302)$ says of Green's book that the latter's "sympathies lie with the eight condemned anarchists, whom he values as true martyrs to labor's cause," continuing that "Parsons, Spies, et al. did not throw the bomb at Haymarket, nor did they participate in a conspiracy to do so, but they did play with dynamite, and those who do so, as the old saying goes, suffer the consequences" (302).

Another way in which de Cleyre seems to be indefatigably anarchist lies in her sympathies with Peter Kropotkin, whom she thought of as a person "of scientific pre-eminence" (De Cleyre 2005, 54) and as "the greatest man, save Tolstoy alone, that Russia has produced" (Avrich 1978, 109). Avrich documents her two meetings with the Russian anarcho-communist thinker that took place in London, England in 1897, the first at the apartment of Will Wess, and the second at Kropotkin's house (109).

DeLamotte (2004, 39) describes de Cleyre as being "profoundly influenced by Peter Kropotkin." Reichert (1976, 342) writes: "Basically a moralist, Voltairine reflected the same profound grasp of the power of ethical thought as did Peter Kropotkin." Elsewhere (346), he adds, "Like Peter Kropotkin, whom she greatly admired, Voltairine de Cleyre had no illusions that anarchism might be actually implemented in her lifetime-or ever, for that matter."

There are certainly a number of similarities between de Cleyre's and Kropotkin's ideas. Marsh $(1981,132)$, for example, argues that both anarchists ultimately saw the solution to women's exploitation by men as 
residing in a future utopia where it would be unnecessary for people to work very many hours each week. DeLamotte comments:

From de Cleyre's perspective, achieving Kropotkin's "plenitude of existence: ... depended integrally on the elimination of "sex slavery" as one of the underpinnings of the current social order. (DeLamotte 2004, 107)

Similarly, when DeLamotte $(2004,63)$ notes that de Cleyre believed "the state is by nature violent and exists to protect a minority's appropriation, by force, of the earth's resources, of technological resources, and of human labor," she points out that de Cleyre even attributed her own shooting by Helcher to the latter's dearth of "proper food and healthy labor" (DeLamotte 2004, 63, Avrich, 174). The writings of Kropotkin, many of which appeared in the form of pamphlets, are full of such accounts, and Avrich $(1978,168)$ notes that de Cleyre was impressed by one of collection of these polemics, Fields, Factories and Workshops. In another work, Mutual Aid, Kropotkin gives the example of horses and cattle in Siberia which did not attain their full potential due to the harshness of conditions ([1914] 1955 73-74); elsewhere, he frequently describes the plight of laborers so overworked that they could not think clearly enough to analyze their situation. Avrich $(1978,167)$ concludes that "[l]ike Kropotkin ... she was the natural enemy of an economic system that reduced labor to sheer drudgery while starving the workers."

Additionally, Reichert (1976, 350), points out that "Voltairine de Cleyre insisted with Kropotkin that society must reflect man's spiritual concern for his fellowman." For Kropotkin ([1914] 1955), this concern is surely innate, learned when we were simpler species, and it has been preserved and modified through evolution. DeLamotte identifies de Cleyre's opinion as being like Kropotkin in the conviction that "the formal details of the new society would develop naturally" (DeLamotte 2004, 26).

Finally, even though Nettlau does not see de Cleyre as a true anarchist, in the following passage, he defines de Cleyre's beliefs in a way that many other commentators would claim makes both de Cleyre and Kropotkin explicitly anarchists of a distinctive type:

Voltairine de Cleyre and C.L. James gave expression to these first feelings of revolt on the part of those who, while they were not anarchists in the present accepted sense of the word, were nevertheless filled with horror at the spectacle of statism and the insolent domination of monopolists over the natural riches of half a continent. (Nettlau, 1996, 31)

Voltairine de Cleyre was also heavily influenced by individualistic anarchism, and specifically by the strain known as "American Anarchism," a 
belief system that is primarily associated with the writings of Tucker, Josiah Warren, and Lysander Spooner. Emma Goldman ([1932] 2005, 34) notes that de Cleyre was inspired by reading Tucker's periodical, Liberty, to which she would later contribute. Presley (2005a, 47) concurs that a "major influence that propelled Voltairine toward anarchism was Benjamin Tucker's individualist anarchist journal Liberty."

However, such comparisons can sometimes be exaggerated. Sartwell distinguishes de Cleyre's anarchism from that of Goldman, with whom it has often been associated, as follows:

Where Goldman drew on the work of European thinkers such as Kropotkin and Bakunin, de Cleyre associated her thought with Americans such as Paine, Jefferson, Emerson, and the individualist writer Benjamin Tucker. Where Goldman was given to the free expression of desire, de Cleyre spent much of her youth in a nunnery and even after she rejected organized religion she remained quite a severe ascetic. $(2005,3)$

It is difficult to know where to start a rebuttal of Sartwell's argument, since it contains so many disputable points. De Cleyre's interest in Kropotkin and the many similarities between her ideas and his have been explored in earlier paragraphs of this paper. De Cleyre spent no time as a nunnery novice; rather, she merely attended school in a Catholic convent, where she had the formal status of a Protestant, took classes throughout the day, was required to pray, and rebelled against its teachings, even running away (Avrich 1978, 31). She had relationships with several men to whom she was not married, and gave birth to a child out of wedlock. Sartwell himself names two men with whom she was romantically involved, Samuel Gordon $(2005,4)$ and James Elliott (6), and notes that "[s]he had several lovers over the years" (6). And her anarchism is surely mainstream in many ways, not really American Anarchism in all of the aspects we would associate with Tucker. Some scholars, such as Delamotte $(2004,25)$, argue that de Cleyre moved from being an individualistic thinker to a more communitarian and Europeaninfluenced anarchist later in her life. Others, would say that she embraced a range of ideas that have been associated with different kinds of anarchism. Rosemont (1990, 10), sees her as being beyond classification. He maintains that "De Cleyre's anarchism was largely inspired by poets."

Nonetheless, the influence of individualistic anarchism can be seen in de Cleyre's ardent defense of what Hogeland and Klages (2004, 1341-42) refer to as "the sanctity of the individual," a passion that they trace back to the asceticism of her Catholic school training. She opposed authority and the compulsion that it invoked, including loyalty to any particular strain of anarchism itself (De Cleyre [1914] 2005, 115-117; DeLamotte 2004, 108). 
Marsh (1981, 125-27) also references the time de Cleyre spent at the convent school in Ontario, noting that some anarchist commentators have in consequence cast her as engaged in resisting the oppression of dogma; she mentions that, later in life, de Cleyre herself presents her years at Our Lady of the Lake as having this effect. Presley $(2005 b, 24)$ portrays de Cleyre as advocating the "complete individuality of woman."

\section{Voltairine de Cleyre as a Feminist}

Another influence upon de Cleyre was Dyer D. Lum (1839-1893), who is mentioned above, and who was her teacher, friend, and erstwhile sweetheart. Brooks $(1993,57)$ writes that one of Lum's skills was the fact that he "could bridge ethnic differences, for despite being native-born, he had substantial contacts with immigrant radicals." That description applies also to de Cleyre, who had many connections to émigrés in the United States, to anarchists in Europe, and to revolutionists in Mexico. Likewise, as Marsh (1981, 129) observes, Lum and de Cleyre shared a "frustration with the factional disputes that split the anarchist movement and . . alienated working-class converts."

Although de Cleyre and Lum were lovers for a while, her pregnancy resulted from a relationship with James Elliott (1849-1935). Too unhealthy to risk an abortion, de Cleyre did not want to be a mother-Palczewski $(1995,56)$ says "she refused to marry"-and she blamed Ellis for the pregnancy (DeLamotte 2004, 84). The child, Harry de Cleyre, was apparently not told who his mother was until he was fifteen (Marsh 1981, 130, 147) and he was seventeen before they met (Goldman [1932] 2005, 42). Reichert writes:

Like Rousseau, she could develop a carefully wrought theory by which to educate the children of the world but had no ability to love children of her own. $(1976,341)$

For Marsh, Lum's influence on de Cleyre was necessarily limited, because he did not address the condition of women explicitly. She writes:

Although Dyer Lum directed and to a large extent shaped de Cleyre's early education as an anarchist, ... De Cleyre's active exploration of the Woman Question, manifested both in her published work and private correspondence, dated from 1891, a year after the birth of her son. Prior to that time, although she had demanded the freedom to make her choices as a human being without the hindrance of feminine constraints, she was less aware of the costs of such an assertion; motherhood forced her to confront the consequences of her stance. (Marsh 1981, 131-32) 
Marsh (130) finds "De Cleyre's obvious neglect of her son" to be "somewhat puzzling." However, this occurrence might be more understandable if it can be determined that de Cleyre was more committed to radical politics than she was interested in being a mother. Alternatively, perhaps it constitutes evidence that she was a feminist of some kind.

To answer the latter question, it is necessary to say what exactly is denoted by feminism. For many scholars, attempts to define that word are necessarily tricky due to the sheer difficulty of summarizing a wealth of perspectives. Thus, Taylor $(1989,477)$ writes that "contemporary feminist thought encompasses diverse beliefs and is by no means a monolithic perspective." Outshoorn $(2004,5)$ concludes that "contemporary authors, to avoid the deep divisions in present-day feminism, will speak of 'women's movements." Offen $(1988,131)$ says: "As things now stand, scholars have to invent their own definitions of feminism." Similarly, though, perhaps unintentionally, excluding the possibility of males being feminists, Sjoberg writes:

In this era of the increasing importance of gender, exactly what is meant by "feminism" is still unclear. Feminists are women who advocate for gender rights, but what they mean by that and what tactics they employ sometimes seem so diverse that the utility of grouping "feminists" has been questioned. (2006, 31-32)

Sapiro $(1994,478)$ describes feminist theories as being "a constant discussion among the many perspectives," which "continues to change over time." Bunch is able to conclude:

The initial tenets of feminism have already been established-the idea that power is based on gender differences and that men's illegitimate power over women taints all aspects of society, for instance. $(1998,15)$

Nevertheless, Offen cautions that people use feminism in so many different ways, and thus it is necessary for each person to say what they mean by the concept. She continues:

We find contemporary scholars employing both dualistic and tripartite distinctions. Among the dualistic distinctions proposed by scholars and activists in recent years are "old" and "new" feminisms, "social" and "hard-core" feminisms, "first-wave" and "secondwave" feminisms, "classical" and "modern" feminisms, "maximalist" and "minimalist" feminisms, and "humanistic" and "gynocentric" feminism. Tripartite distinctions include the "egalitarian," "evangelical," and "socialist" feminisms identified in the recent British past (i.e., since 1800) by sociologist Olive Banks, and the "liberal," "Marxist," and "radical" feminisms located by 
located by Zillah Eisenstein and others in the contemporary American scene. $(1988,132)$

In the United States, first wave feminism refers to the activities of Susan B. Anthony, Elizabeth Cady Stanton, Lucy Stone, Sojourner Truth, Jeannette Rankin, Myra Colby Bradwell, and others, many of whom came to feminism after fighting to end slavery. This movement was primarily interested in securing rights, particularly the right to vote, but also the ability of women to keep their earnings, and have access to employment such as the legal profession, which Colby Bradwell eventually, after a protracted fight, achieved in Illinois. The means by which these gains were to be achieved was generally through legal and constitutional reforms, including peaceful protest. But anarchism favors the attainment of people's needs, rather than the acquisition of rights (see Kropotkin [1927] 1968, 60-61; Shone 2000; Sullivan and Sullivan 1998), and anarchists, including de Cleyre, are often willing to use violence to attain at least some of their goals, so it is hard to see de Cleyre as advocating first wave feminism. In "Direct Action." she wrote:

It would be very stupid to say that no good results are ever brought about by political action; sometimes good things do come about that way. But never until individual rebellion, followed by mass rebellion, has forced it. (De Cleyre [1914] 2005, 231)

In "The Case of Woman Versus Orthodoxy," where de Cleyre (2005, 219) credits "in every freedom-going spark the risen dead," specifically naming Lucretia Mott and "that grand old negress, Sojourner Truth," she argues for basic economic equality between men and women, which she calls "the right of self-maintenance" (218), but which, in characteristically anarchistic fashion, could be viewed as really being a need rather than a right. Furthermore, for de Cleyre, to achieve fulfillment of such needs requires the acceptance of revolutionary methods:

There will be no cessation in that revolt, no matter what ticket men vote or fail to vote, until the chains are broken. (De Cleyre [1914] $2005,238)$

Second wave feminism is the term used for the renewed activities of the 1960s, 1970s, and 1980s. In the United States, many credit Betty Friedan with sparking this resurgence. Mitchell writes:

If a single inspiration for the movement is to be cited, it was the publication in 1963 of Betty Friedan's The Feminine Mystique. (1973, 52)

Attacking what she saw as the melancholy and lack of creative opportunities that contemporary women experienced in their daily lives as they worked at home, Friedan $(1964,338)$ lambasted the "feminine mystique" that "says that 
the highest value and the only commitment for women is the fulfillment of their own femininity" (37). Dolan, Deckman, and Swers summarize the message of this book as follows:

Friedan found that these women were deeply dissatisfied with their lives as housewives and could not reconcile the intellectual and social stimulation of their college years with the isolation and routine of housework and child care. $(2007,25)$

Friedan's contribution, however, is controversial, since she published a second key volume at the beginning of the 1980s, called The Second Stage. There, Friedan $(1981,23)$ suggested that there was now "a danger today in feminist rhetoric, rigidified in reaction against the past, harping on the same old problems in the same old way, leaving unsaid what's really bothering women and men in and beyond the new urgencies of personal economic survival." Now a feminist mystique was abroad, attacking the institution of the family, itself doing substantial damage to women's lives (McElroy 2001, 103; Rosen 2000, 335).

In a development that has been apparent since the 1990s, though some of its roots go back much earlier, dissatisfaction with second wave maxims and achievements prompted the categorization of a third, less polemical current. Shaw and Lee $(2004,11)$ say of these thinkers that, "[c]oming of age during the Reagan years of the 1980s, they grew up with feminism as well as the resistance or backlash to it. . Third wave issues focus on sexuality and identity and tend not to have arisen from a mass-based social movement." Iannello writes that:

Third-wave feminism can be described as individual, multicultural, and sexual. ... Third-wave feminism is sexual in that it focuses on the pleasures of womanhood through sexual freedom. An example of this new sexuality is reflected in popular culture through television shows such as Sex and the City, where female characters explore issues of female sexual freedom across both gender and generational lines. $(2005,335)$

Alternatively, Cornell argues:

The feminism I defend sets the reconciliation of sexual freedom with social equality at the heart of its political program. But we need to rethink the fundamental premises of our feminism if we are to achieve that reconciliation. $(1998$, xii)

Second wave feminists have not been warm to such developments. In particular, they have tended to see third wavers as sounding a retreat from core values, perhaps out of fear of men and of the concomitant abhorrence that some feminist tracts have engendered. In particular, there is an oft-stated 
view that younger women have somehow been intimidated away from articulating a (second wave) philosophy that remains in their interest. For example, Steinem complains:

Given the danger to a male-dominant system if young women stop internalizing this political message of derived identity, it's no wonder that those who try to kick the addiction—and, worse yet, to help other women do the same-are likely to be regarded as odd or dangerous by everyone from parents to peers. $(1983,214-15)$

Harding writes in similar fashion:

The term "feminism" is too radical for some people and too conservative for others. It is common today to find people struggling specifically to improve women's conditions but refusing to characterize their efforts as feminist. $(1991,23)$

Hooks concludes:

Say that you are feminist to most men, and automatically you are seen as the enemy. You risk being seen as a man-hating woman. Most young women fear that if they call themselves feminist, they will lose male favor, they will not be loved by men. $(2004,107)$

Hogeland echoes the sentiment as follows:

Young women may believe that a feminist identity puts them out of the pool for many men, limits the options of who they might become with a partner, how they might decide to live. $(2004,566)$

Do second-wavers misunderstand the reason why younger women are reluctant to apply the term feminist to themselves? Sometimes, their approach reads like a proclamation that, if you are unable to agree with me completely, accepting my ideology without any revisions, this must necessarily be because you are terrified of men and their potential reaction. Ironically, such rationalizations often emphasize women's "choice" of how to live their lives, though it is frankly hard to see many women today as having much actual choice, given their economic circumstances, a sentiment with which de Cleyre would surely agree. Excluded from the second wavers' meditations is apparently the possibility that some women might "choose" equality, rather than favoritism for women. Their explanations identify men, once again, as being at fault. Yet it is hard to believe, precisely because of the prolific accomplishments of the second wave, that most men today would reject a woman because she is a feminist.

Not everyone has been willing to accept second wave feminism's excuses for the lessening of its support. Although Hymowitz advocates traditional marriage and writes from a conservative point of view, she 
appreciates the failure of second wave feminists to welcome third wave adjustments:

It's no wonder that feminists have a hard time accepting that trends like these could represent what women actually want. After all, feminists of the 1960s and '70s took to the streets on the premise that women wanted to escape from the prison house of the bourgeois home. (Hymowitz 2006, 130)

In a chapter called "The End of Herstory," Hymowitz concludes: "But this explanation falls far short. Feminism is not simply suffering from a P. R. problem. It's just over. As in finished' (2006, 127).

From within the second-wave movement, Phyllis Chesler has criticized her colleagues too, and has also been skewered in response. More balanced than Hymowitz, she writes:

Young people may embrace ideals and principles that are quite demanding. Not everyone can "keep on keeping on" for the rest of their lives. In some ways, Second Wave feminism had its day, did its work in the world-it's over. On the other hand, let me suggest that the Second Wave of feminism is not yet altogether over; our successors are still continuing this Wave's work. (Chesler 2001, 441)

While it might be reasonable to dismiss Hymowitz as a conservative anti-feminist, application of the second term to Chesler, or to a third wave "pro-men" type of feminist such as Camille Paglia is more problematic. Shaw and Lee $(2004,12)$ beg the question when they define "anti-feminist activity" as including "women who claim to be feminists yet are resistant to its core principles." They then name Paglia and her ally, Christina Hoff Sommers, as members of this group of "anti-feminists" (12). But Paglia and Sommers would see themselves as "equity feminists," opponents of the extremism that obliges Shaw and Lee to define them as opponents (McElroy 2001; Paglia 1991; Sommers 1994).

The early 1990s saw the appearance of Susan Faludi's book, Backlash: The Undeclared War Against American Women, which likewise attempts to explain the downturn in support for second wave ideals by resisting all criticism and blaming men (Rosen 2000, 334). Faludi writes:

The backlash decade produced one long, painful and unremitting campaign to thwart women's progress. . . News-stands and airwaves may have been awash with frightening misinformation on spinster booms, birth dearths, and deadly childcare-yet women continued to postpone their wedding dates, limit their family size and combine work with having children. $(1992,492)$

Sapiro sums up Faludi's book as saying that: 
Following some of the early successes of the new women's movement, a vehement backlash developed in almost all walks of life during the 1980s that warred against the advances women had made and were further claiming, and that sought to restore women to a more traditional and subordinate place. $(1994,466)$

However, others would see the situation differently. Paglia (1994, 180), for example, speaks of "a problem that the feminist establishment refuses to face: career women in the Anglo-Saxon world have desexed themselves. Latin countries still acknowledge and celebrate the sexual power of woman." And Kipnis concludes, with an eye on the failings of both second and third wave approaches:

With feminism's declining drawing power, the present condition of women has often been designated "postfeminism." The main difference is this: in place of yesterday's tyrannical husbands and social restrictions, today we have the girlfriend industry, and voluntary servitude to self-improvement ... women end up more corseted and restricted than ever. $(2006,10-11)$

For Delamotte (2004, 109-111), Voltairine de Cleyre's story “'The Heart of Angiolillo," about an anarchist couple's relationship that is undermined by the woman's need to perform domestic labor, is a good vehicle for the writer's feminist ideas, allowing her to present women's work in the home as a form of labor exploitation. Of course, such irony involving intention and reality has been noticed also by many others, including Abigail Adams, who, in her correspondence with her husband, wryly assessed the accomplishments of the Founding Fathers; Elizabeth Cady Stanton and Lucretia Mott, who found themselves segregated from men at an anti-slavery conference in England in 1840; and by Kropotkin ([1906] 1990, 154), who warns that women liberated from a life working at home "will always throw domestic toil on to another woman."

However, a point that perhaps needs to be made is that, if gender slavery is a form of economic or class oppression, with gender being one of the bases for social stratification, then, de Cleyre's analysis, at root, may not be distinctively feminist. Is de Cleyre here not denying the fundamental importance of gender to wife exploitation, and relegating it to a sub-species of class warfare? This issue will be discussed in more detail later in the paper.

When DeLamotte $(2004,111)$ continues by noting "the imbrication of gender oppression with other forms of oppression in de Cleyre's feminist theory," she does not address the topic of whether de Cleyre may not really have a feminist theory at all, but, rather, an anarchist theory that, quite naturally, rejects the oppression of women. And when she (115) states that "De Cleyre's analysis of power relations in general" is "deeply intertwined 
with a more specific analysis of women's subordination," again she may be indicating little more than the fact that anarchism's desire for liberty includes women too.

Furthermore, when de Cleyre writes that "[m]arriage is not in the interest of women. It is a pledge from the marrying man to the male half of society" (De Cleyre 2005, 223; DeLamotte 2004, 81), she expresses a view that is clearly not shared my the vast majority of feminists today, nor has it been throughout the history of the last two hundred years. Similarly, as it is explicated by Presley, de Cleyre's approach to men is quite atypical:

Her own unfortunate experiences with most of her lovers, who even without the ties of formal marriage, treated her as a sex object and servant, convinced Voltairine that even living with a man was to be avoided. (2005b, 24)

Speaking of the writer's essay, "The Gates of Freedom," Marsh brings out the anarchism in de Cleyre's position:

[D]e Cleyre wanted women-in countless singular defiant acts-to challenge traditional feminine expectations, to refuse to marry, to bear children, or to fulfill wifely and maternal duties. In effect, she advocated a leaderless general strike against marriage and motherhood. Her goal in this essay was to find an anarchist solution to the problem of female subordination. (Marsh 1981, 133)

Marsh continues as follows:

De Cleyre's importance as a feminist rests primarily on her willingness to confront issues that the organized women's rights movement sidestepped or avoided, such as the emotional and psychological (in addition to the economic) dependence on men within the nuclear family structure, and female sexuality. She also lived in conformity with her feminist principles, which forced those who came into contact with her to confront her philosophy in the particular as well as in the abstract. (Marsh 1981, 146)

Here, Marsh is correct that mainstream feminists have not generally argued for abandoning their children or rejected the institution of marriage. When DeLamotte (2004, 10-11) writes that "[o]ne of De Cleyre's major interests was the question of how women in particular can resist the configuring of their inner lives by the social, political, and economic configurations of an oppressive society," again, the same issues can be raised.

As Marsh (1981, 153-55) perhaps realizes, because she discusses Friedrich Engels in some detail, an apt comparison is with The Origin of the Family, Private Property, and the State, by Engels, which was written after Marx's death, and which discusses the development of the family as an institution. 
The view articulated by others mentioned above, including Voltairine de Cleyre, that, in marriage, stratification is conducted on the basis of gender, was also held by Engels, who argued:

In the great majority of cases today, at least in the possessing classes, the husband is obliged to earn a living and support his family, and that in itself gives him a position of supremacy, without any need for special legal titles and privileges. Within the family he is the bourgeois and the wife represents the proletariat. (Engels 1886)

Building on the ideas of Engels, whom she says had "many valuable insights," the British sociologist, Juliet Mitchell $(1973,79)$ suggests that, while the modern family may have functioned appropriately under a feudal system, it has today, under capitalism, become an instrument of oppression for women (152-53). She describes the transformation of the institution of the family as follows:

[T] he peasant masses of feudal society had individual property; their ideal was simply more of it. Capitalist society seemed to offer more because it stressed the idea of individual private property in a new context ... Thus it offered individualism (an old value) plus the apparently new means for its greater realization-freedom and equality (values that are conspicuously absent from feudalism). However, the only place where this ideal could be given an apparently concrete base was in the maintenance of an old institution: the family. Thus the family changed from being the economic basis of individual private property under feudalism to being the focal point of the idea of individual private property under a system that banished such an economic form from its central mode of production—capitalism. (Mitchell 1973, 154)

She means in the last sentence that, under capitalism, most people do not own or control their own piece of land any more; instead, big businesses own factories where men and women go to work $(1973,153)$.

The family, then, lives beyond the period of its usefulness, as an ideal that does not really benefit women, but which motivates them to toil, so that their children will thrive, or at least not starve. In fact, the family has already disintegrated physically, because its members now labor in different places and for different bosses, and its members may spend little actual time together, and have few interests in common. But the idea of the family and the commitments it engenders make women tolerate men, or even suffer their violence (156-58).

Arguably, de Cleyre's life and writings are better understood as being anti-family in the way of Mitchell's analysis, which can reasonably be described as feminist, but which is not, like the majority of feminist writings, 
concerned about improving the status of women within the flawed institution of the family. However, many contemporary American feminists, including Betty Friedan, the equity feminists such as Camille Paglia and Christina Hoff Sommers, and the third wavers generally reject such radical views. If de Cleyre is rightly to be seen as a feminist, it could be in the sense that she defends the victims of marriage, who live lives that are alien to her anarchist sensibility. Marsh probably comes closest to agreement with this when she writes:

It was not the legal form of marriage, but the notion of men and women living together in a nuclear family, whether formalized or not, which she found intolerable. $(1981,144)$

\section{De Cleyre: More of an Anarchist than a Feminist?}

If Voltairine de Cleyre is to be considered a feminist, then in what ways would that appellation truthfully apply? What beliefs make people nonfeminists or incompatible with feminism? De Cleyre's writings may be companionable with many of the multiple propositions of feminism, but perhaps she can still not reasonably be termed a feminist herself-at least, not without some qualification. As was argued above, she is not easily reconciled with first or third wave feminists, with equity feminism, nor with second wave ideas of people like Friedan or Chesler, who call for moderation of the second wave position. Her ideas have been embraced by some mainstream second-wavers, but the differences between de Cleyre's opinions and theirs are extensive.

One reason for considering de Cleyre as an anarchist, but not as a feminist, would be the priorities revealed in her own writings. She developed the much-praised piece, "Why I Am An Anarchist," after all, but she never produced a polemic titled "Why I Am A Feminist"- - just some pieces that attacked the institution of marriage, with both skill and force. Furthermore, de Cleyre saw her predicament as being something that was shared by her fellow man. When she writes about contemporary poverty, she laments the situation whereby "any man who must wait the complicated working of a mass of unseen powers before he may engage in the productive labor necessary to get his food is the last thing but a free man" $(2005,58)$. Elsewhere, she claims that people "who look on Man, as most Anarchists do," see the species "as a link in the chain of evolution" (69). She was, after all, an anarchist, and she had no issues with describing herself as a part of a species known as "man." She was a writer, moreover, who was very particular about the words that she used. 
Anarchism is at the heart of de Cleyre's oeuvre, and, talking about a defining moment in her intellectual development, she confesses that "[t]he State had now disappeared from my conception of society; there remained only the application of Anarchism" (De Cleyre 2005, 64). Implicitly, Horwitz, Kowal, and Palczewski $(2008,663)$ seem to accept this when they write:

De Cleyre's goal clearly was empowerment, but not merely the empowerment of women. Instead, she sought to instigate general resistance in all members of her audience.

When Palczewski $(1993,147)$ describes de Cleyre's disdain for marriage, she writes that " $[t]$ he apologists for this slavery were the traditional anarchist demons: church and state." Even when de Cleyre attacks the family unit and the way that men behave in it, ultimately she is making an anarchist argument against the suppression of the individual. Similarly, Palczewski $(1995,56)$ writes:

The institutions that bound women to men and children caused de Cleyre to question the role women were allotted in life. She concluded that liberty, not the state, was the solution. (Palczewski 1995, 56)

This is anarchism, with de Cleyre's reference to liberty reminding the reader of the doctrines of its more individualist forms; it evokes Tucker, Lysander Spooner, or Max Stirner, for example. This is the credo that Madison (1943, 444) is describing when he calls Tucker the "chief American exponent of individualist anarchism, or the doctrine of the stateless society with complete and equal liberty for all." This is not a position that most feminists have held. As de Cleyre herself expressed it in her essay, "Anarchism":

This is the particular message of Anarchism to the worker. ... It simply calls upon the spirit of individuality to rise up from its abasement, and hold itself paramount. (De Cleyre 2005, 72)

When Palczewski $(1995,62)$ writes that "[t]he only limits de Cleyre seemed willing to acknowledge were those established by the individual woman" the question can be asked, would it not be better to say "the individual person," because that, in a nutshell, is what individualistic anarchism is about, regardless of whether or not the individual is female or male?

Marso applies a second wave agenda to Emma Goldman, whom she argues, "is far better known for her dramatic life and for her anarchism than for any contribution to political and feminist theory" (2003, 305). In addition to another criticism that might be made of this argument, which would point out that anarchism has given much to political theory, it can also be said that Marso seems to want, like some of the appraisers of Voltairine de Cleyre, to craft Goldman as a feminist, even though the latter has traditionally been 
considered, and was even deported from the United States because she was, an anarchist. For instance, she writes: "Goldman delivers an anarchist dream of woman's desire to be free from oppressive social conditions and expectations" (316). But surely, this is the dream of all anarchists, irrespective of their gender?

To craft de Cleyre as a feminist, it is perhaps necessary to employ a definition such as that of Shaw and Lee $(2004,9)$, who write that "[b]ecause feminism is politics of equality, it anticipates a future that guarantees human dignity and equality for all people, women and men." That fits de Cleyre appropriately, but it needs to be pointed out that, if such a definition represented the main concern of many feminists today, perhaps we would see more of them campaigning to end male on male rapes in jail, rather than viewing rape as a crime that personifies gender relations.

Individualistic anarchism is also to be found near the beginning of "Those Who Marry Do Ill," an essay that accounts for some of the designation of Voltairine de Cleyre as a feminist. She writes:

What is the growing ideal of human society ... ? ... [T] he free individual; a society whose economic, political, social, and sexual organization shall secure and constantly increase the scope of being to its several units; whose solidarity and continuity depend upon the free attraction of its component parts, and in no wise upon compulsory forms (De Cleyre 2004, 12; 2005, 198).

In the absence of marriage, de Cleyre also advocates anarchism and individuality in sexual relations:

I would have men and women so arrange their lives that they shall always, at all times, be free beings in this regard as in all others. The limit of abstinence or indulgence can be fixed by the individual alone, what is normal for one being excess for another, and what is excess at one period of life being normal at another. (De Cleyre 2004, 14; 2005, 199)

In fact, de Cleyre's viewpoint resembles not those of most feminists, but rather that of Benjamin Tucker ([1892] 1972, 15), who, for example, writes of his desire for "a time when every individual, whether man or woman, shall be self-supporting, and when each shall have an independent home of his and her own." De Cleyre's commitment to gender equality is apparent here, as it is in "Sex Slavery," where she criticizes gender role socialization. She is dismissive not only of the manner in which girls are "restrained," but also of the way that boys are likewise "laughed at as effeminate, silly girl-boys if they want to make patchwork or play with a doll" (De Cleyre 2004, 101; 2005, 235). 
Voltairine de Cleyre was an outstanding political thinker who valued liberty and sought equality for men and women within an anarchist framework of social justice that would watch over the needs of all people, regardless of gender. To that end, she advocated the abolition of marriage, which she considered a repressive and unnecessary institution. Such a program is compatible with many feminist goals, but it is not specifically a feminist approach, and thus the attribution of the adjective "feminist" when de Cleyre is mentioned often substantially distorts the record of her many intellectual achievements. She can legitimately be called a feminist, if the specific context of that term is outlined. Nevertheless, the greater truth is that she was an anarchist of the first rank, and is well worth reading for that reason, and for that reason alone.

\section{References}

Avrich, Paul. 1978. An American Anarchist: The Life of Voltairine de Cleyre. Princeton, NJ: Princeton University Press. - 1980. "Introduction.” In De Cleyre 1980.

. 1984. The Haymarket Tragedy. Princeton, NJ: Princeton University Press.
. 1990. Anarchist Portraits. Princeton, NJ: Princeton University Press.

Best, Steven, and Anthony J. Nocella, III. 2007. "Behind the Mask:

Uncovering the Animal Liberation Front." www.calaonline.org/TOFF/Behind_the_Mask.pdf (October 18, 2007).

Brammer, Leila R. 2000. Excluded from Suffrage History: Matilda Joslyn Gage, Nineteenth-Century American Feminist. Westport, CT: Greenwood.

Brigati, A. J. 2004. “Introduction.” In De Cleyre, 2004.

Bright, Crystal Dawn. 2006. "Cakalak Thunder: The Meaning of Anarchy, Value and Community in the Music of Greensboro's Protest Drum Corps.” M.Mus. thesis. Florida State University.

Brooks, Frank H. 1993. "Ideology, Strategy, and Organization: Dyer Lum and the American anarchist movement." Labor History 34:57-83. 
Brooks, Frank H., ed. 1994. The Individualist Anarchists: An Anthology of Liberty (1881-1908). New Brunswick, NJ: Transaction.

Brouwer, Daniel C. 2004. "Privacy, Publicity, and Propriety in Congressional Eulogies for Representative Stewart B. McKinney (R-Conn.)" Rhetoric \& Public Affairs 7:191-214.

Bunch, Charlotte. 1998. "Not by Degrees: Feminist Theory and Education." In Women's Lives: Multicultural Perspectives, ed. Gwyn Kirk and Margo Okazawa-Rey. Mountain View, CA: Mayfield.

Carter, Everett. 1950. “The Haymarket Affair in Literature.” American Quarterly 2:270-278.

Chesler, Phyllis. 2001. Woman's Inbumanity To Woman. New York: Thunder's Mouth/ Nation.

Cornell, Drucilla. 1998. At the Heart of Freedom: Feminism, Sex, and Equality. Princeton: Princeton University Press.

Debs, Eugene V. 1990. Letters of Eugene V. Debs. Volume I. Ed. J. Robert Constantine. Champaign: The University of Illinois Press.

De Cleyre, Voltairine. [1914] 2005. Selected Works of Voltairine de Cleyre. Ed. Alexander Berkman. Reprint. New York: Elibron.

- 1980. The First Mayday: The Haymarket Speeches 1895-1910. Sanday, Orkney: Cienfuegos.

— 1990. Written in Red: Selected Poems. Chicago: Charles H. Kerr.

- 2004. The Voltairine de Cleyre Reader. Ed. A. J. Brigati. Oakland, CA: AK Press.

- 2005. Exquisite Rebel: The Essays of Voltairine de Cleyre-Anarchist, Feminist, Genius. Ed. Sharon Presley and Crispin Sartwell. Albany: State University of New York Press.

De Grazia, Edward. 2006. “The Haymarket Bomb." Law and Literature 18:283-322.

DeLamotte, Eugenia C. 2004. Gates of Freedom: Voltairine de Cleyre and the Revolution of the Mind. Ann Arbor: University of Michigan Press.

DeMille, Anna George. 1946. "Henry George: Haymarket and Tariff Reform." American Journal of Economics and Sociology 5:545-551.

Dolan, Julie, Melissa Deckman, and Michele L. Swers. 2007. Women and Politics: Paths to Power and Political Influence. Upper Saddle River, NJ: Pearson Prentice Hall. 
Dubofsky, Melvyn. 2007. Book review of Green 2006. Industrial and Labor Relations Review 60:301-302.

Engels, Friedrich. 1886. The Origin of the Family, Private Property, and the State. www.marxists.org/archive/marx/works/1884/origin-family/index.htm (November 4, 2007).

Faludi, Susan. 1992. Backlash: The Undeclared War Against Women. London: Vintage.

Fidler, Geoffrey C. 1985. “The Escuela Moderna Movement of Francisco Ferrer: "Por la Verdad y la Justicia." History of Education Quarterly 25:103-132.

Friedan, Betty. 1964. The Feminine Mystique. New York: Dell. 1981. The Second Stage. New York: Summit.

Goldman, Emma. [1917] 1969. Anarchism and Other Essays. 3rd. ed. Reprint. New York: Dover. [1932] 2005. "Voltairine de Cleyre." In De Cleyre 2005.

Grace, Russo Bullaro. 2007. Man in Disorder: The Cinema of Lina Wertmüller in the 1970s. Leicester, Leicestershire: Troubador.

Green, James. 2006. Death in the Haymarket: A Story of Chicago, the First Labor Movement, and the Bombing That Divided Gilded Age America. New York: Pantheon.

Guaneri, Carl. 1985. "Haymarket Through the Anarchists' Eyes.” Reviews in American History 13:76-79.

Halker, Clark D. 1991. For Democracy, Workers and God: Labor Song-Poems and Labor Protest. Champaign: The University of Illinois Press.

Harding, Sandra. 1991. Whose Science? Whose Knowledge? Thinking from Women's Lives. Ithaca: Cornell University Press.

Havel, Hippolite. 1910. “Biographic Sketch: Emma Goldman.” In Goldman [1917] 1969.

- 1914. "Introduction.” In De Cleyre [1914] 2005.

Hecht, Jennifer Michael. 2004. Doubt: A History: The Great Doubters and Their Legacy of Innovation from Socrates and Jesus to Thomas Jefferson and Emily Dickinson. San Francisco: HarperOne.

Henderson, Ariel. 2003. "Symbols of Resistance: A Study of Anarchist Space and Identity in Philadelphia." B.A. thesis. Bryn Mawr College. 
Herrada, Julie, and Tom Hyry. 1999. "Agnes Inglis: Anarchist Librarian.” Progressive Librarian 16:7-10.

Hogeland, Lisa Maria. 2004. "Fear of Feminism: Why Young Women Get the Willies." In Shaw and Lee, 2004.

Hogeland, Lisa Maria, and Mary Klages, eds. 2004. The Aunt Lute Anthology of U.S. Women Writers. Volume 1. San Francisco: Aunt Lute.

Hooks, Bell. 2004. The Will to Change: Men, Masculinity, and Love. New York: Atria.

Horwitz, Linda Diane, Donna Marie Kowal, and Catherine Helen Palczewski. 2008. "Anarchist Women and the Feminist Ideal: Sex, Class, and Style in the Rhetoric of Voltairine de Cleyre, Emma Goldman and Lucy Parsons." In The Rhetorical History of the United States, ed. Martha Soloman Watson and Thomas Burkholder, Volume 5. East Lansing: Michigan State University Press.

Huberman, Jack. 2007. The Quotable Atheist: Ammunition for Non-Believers, Political Junkies, Gadflies, and Those Generally Hellbound. New York: Nation.

Hymowitz, Kay S. 2006. Marriage and Caste in America: Separate and Unequal Families in a Post-Marital Age. Chicago: Ivan R. Dee.

Iannello, Kathleen P. 2005. "The Political is Personal: Third-Wave Feminist Perspectives on Power." In Women in Politics: Outsiders or Insiders? ed. Lois Duke Whitaker. 4th. ed. Upper Saddle River, NJ: Pearson Prentice Hall.

Kaye, Harvey J. 2005. Thomas Paine and the Promise of America. New York: Hill and Wang.

Kensinger, Loretta. 2003. "Plugged in Praxis. Critical Reflections on U.S.

Feminists, Internet Activism, and Solidarity with Women in

Afghanistan." Journal of International Women's Studies 5:1-28.

Kipnis, Laura. 2006. The Female Thing. New York: Pantheon.

Kropotkin, Peter. [1899] 1968. Fields, Factories and Workshops. Reprint. New

York: Greenwood.

. [1906] 1990. The Conquest of Bread. Montréal: Black Rose.

. [1914] 1955. Mutual Aid: A Factor of Evolution. Boston: Extending Horizons.

[1927] 1968. Kropotkin's Revolutionary Pamphlets. Reprint. Ed. Roger N. Baldwin. New York: Benjamin Blom. 
Landsman, Stephan. 1986. Book review of Avrich 1984. Michigan Law Review 4/5:824-841.

Laslett, J. H. M. 1987. Book review of Haymarket Scrapbook ed. by Dave Roediger and Franklin Rosemont. The Journal of American History 74:192-193.

Madison, Charles A. 1943. "Benjamin R. Tucker: Individualist and Anarchist.” The New England Quarterly 16:444-467.

Marsh, Margaret S. 1978. "The Anarchist-Feminist Response to the "Woman Question' in Late Nineteenth-Century America." American Quarterly 30:533-547.

-1981. Anarchist Women 1870-1920. Philadelphia: Temple University Press.

Marso, Lori Jo. 2003. "A Feminist Search for Love: Emma Goldman on the Politics of Marriage, Love, Sexuality and the Feminine." Feminist Theory 4:305-320.

Martin, James J. 1970. Men Against the State: The Expositors of Individualist Anarchism in America, 1827-1908. Colorado Springs: Ralph Myles.

McElroy, Wendy. 2000. "The Schism Between Individualist and Communist Anarchism in the Nineteenth Century." Journal of Libertarian Studies 15:97-123.

- 2001. Sexual Correctness: The Gender-Feminist Attack on Women. Reprint. Jefferson, NC: McFarland. 2003. The Debates of Liberty: An Overview of Individualist Anarcbism, 1881-1908. Lanham, MD: Lexington.

McKinley, Blaine. 1982. “The Quagmires of Necessity”: American Anarchists and Dilemmas of Vocation." American Quarterly 34:503-523.

1987. "“A Religion of the New Time': Anarchist Memorials to the Haymarket Martyrs, 1888-1917.” Labor History 28:386-400.

Meltzer, Albert. 1996. I Could Paint Golden Angels: Sixty Years of Commonplace Life and Anarchist Agitation. San Francisco: AK Press.

Mitchell, Juliet. 1973. Woman's Estate. New York: Vintage.

Molyneux, Maxine. 1986. "No God, No Boss, No Husband: Anarchist

Feminism in Nineteenth-Century Argentina." Latin American Perspectives 13:119-145.

Mullaney, Marie Marmo. 1990. "Sexual Politics in the Career and Legend of 
Louise Michel." Signs: Journal of Women in Culture and Society 15:300-322.

Nettlau, Max. 1996. A Short History of Anarchism. London: Freedom.

Oberdeck, Kathryn J. 2007. "A Response to Shelley Streeby. American Labor History 19:434-437.

Offen, Karen. 1988. "Defining Feminism: A Comparative Historical

Approach." Signs: Journal of Women in Culture and Society 14:119-157.

Oliver, Willard M. 2007. Book review of Green 2006. The Southwest Journal of Criminal Justice 4:145-151.

Ottanelli, Fraser. 1997. Book review of An Oral History of Anarchism in America by Paul Avrich. The Oral History Review 24:158-160.

Outshoorn, Joyce, ed. 2004. The Politics of Prostitution: Women's Movements,

Democratic States and the Globalisation of Sex Commerce. Cambridge,

Cambridgeshire: University of Cambridge Press.

Paglia, Camille. 1991. Sexual Personae: Art \& Decadence from Nefertiti to Emily

Dickinson. New York: Vintage.

1994. Vamps \& Tramps: New Essays. New York: Vintage.

Palczewski, Catherine Helen. 1993. "Voltairine De Cleyre" In Women Public

Speakers in the United States, 1800-1925: A Bio-Critical Sourcebook, ed.

Karlyn Kohrs Campbell. Westport, CT: Greenwood.

1995. "Voltairine De Cleyre: Sexual Slavery and Sexual Pleasure in

the Nineteenth Century." NWS A Journal 7:54-68.

Pateman, Barry. 2004. "Preface.” In De Cleyre 2004.

Presley, Sharon. 2005a. "Introduction to Part II.” In De Cleyre 2005.

2005b. "The Exquisite Rebel: The Anarchist Life of Voltairine de Cleyre.” In De Cleyre 2005.

Reichert, William O. 1976. Partisans of Freedom: A Study in American Anarchism. Bowling Green, OH: Bowling Green University Popular Press.

Rosemont, Franklin. 1990. “Introduction.” In De Cleyre 1990.

Rosen, Ruth. 2000. The World Split Open: How the Women's Movement Changed America. New York: Viking.

Sakolsky, Ron. 2005. Creating Anarchy. Liberty, TN: Fifth Estate.

Salvatore, Nick. 1985. Book review of Avrich 1984. The American Historical Review 90:772-773. 
Sapiro, Virginia. 1994. Women in American Society: An Introduction to Women's Studies. 3rd. ed. Mountain View, CA: Mayfield.

Sartwell, Crispin. 2005. "Priestess of Pity and Vengeance." In De Cleyre 2005.

Shaw, Susan M., and Janet Lee. 2004. Women's Voices, Feminist Visions: Classic and Contemporary Readings. 2nd. ed. New York: McGraw Hill.

Shone, Steve J. 2000. "Kropotkin's Just Community: A Counterexample to the Theory that Liberal Democracy has Triumphed." Contemporary Justice Review 3:187-204.

Sommers, Christina Hoff. 1994. Who Stole Feminism? How Women Have Betrayed Women. New York: Simon \& Schuster.

Sjoberg, Laura. 2006. Gender, Justice, and the Wars in Iraq: A Feminist Reformulation of Just $W$ ar Theory. Lanham, MD: Lexington.

Steinem, Gloria. 1983. Outrageous Acts and Everyday Rebellions. New York: Holt, Rinehart and Winston.

Streeby, Shelley. 2007. "Labor, Memory, and the Boundaries of Print Culture: From Haymarket to the Mexican Revolution." American Labor History 19:406-433.

Sullivan, Dennis, and Kathryn Sullivan. 1998. "The Political Economy of Just Community: A Radical Interpretation." Paper presented at the annual meeting of the American Society of Criminology, Washington, DC.

Taylor, Verta. 1989. "The Future of Feminism: A Social Movement Analysis." In Feminist Frontiers II: Rethinking Sex, Gender, and Society, by Laurel Richardson and Verta Taylor. 2nd. ed. New York: Random House.

Tone, John Lawrence. 2006. War and Genocide in Cuba, 1895-1898. Chapel Hill: The University of North Carolina Press.

Tucker, Benjamin R. [1892] 1972. State Socialism and Anarchism and Other Essays. Colorado Springs: Ralph Myles.

Wallace, Robert K. 1975. "Billy Budd and the Haymarket Hangings." American Literature 47:108-113.

Weir, David. 1997. Anarchy \& Culture: The Aesthetic Politics of Modernism. Amherst: University of Massachusetts Press.

Wexler, Alice. 1981. "Emma Goldman on Mary Wollstonecraft." Feminist Studies 7:113-133. 